\title{
The Impact of Privatization of Power Sector in Nigeria: A Political Economy Approach
}

\author{
Aminu, Isa \\ Peterside, Zainab Brown \\ Department of Political Science \\ Federal University Lokoja, Nigeria \\ P.M.B 1154, Lokoja, Kogi State
}

\section{Doi:10.5901/mjss.2014.v5n26p111}

\begin{abstract}
This paper discuses the impact of privatization of Power sector in Nigeria. Using the political economy approach, it argues that the privatization of the Power sector in Nigeria is based on capitalist values, ideology, orientation and assumption. The assumption of free market presupposes that the market operates in a competitive environment. This is not however true in the real life situation as power sector privatization in Nigeria has only succeeded in entrusting the collective wealth of the people in the hands of few elites, retrenchment of workers, high electricity bills without commensurate services among other negative impacts. It therefore recommends that there is need for a level playing field for more competent investors to come into the industry .Also, the regulatory body need to check the excesses of the new Distribution companies by regulating tariffs and quality services. This will go a long way in improving the situation.
\end{abstract}

Keywords: Power sector, Power sector Reform, Privatization, Public enterprises, PHCN.

\section{Introduction}

Independence heralded a lot of expectations among Africans, Nigerians not being an exception. In a bid to fast tract socio-economic development and also guard government finances under conditions of capital scarcity and structural defects in private business organizations, Nigeria and most African countries, regardless of ideological dispositions, unavoidably made fairly extensive use of public enterprises (PEs) for resource mobilization, allocation and acceleration of the pace of their economic development in the 1950s through the 1960s (Ojobo, 2005). In both technical and economical perspectives, PEs are seen as: organizations whose primary function is the production and sale of goods and /or services and in which government or other government controlled agencies have an ownership stake that is sufficient to ensure their control over the enterprises regardless of how actively that control is exercised (Tanzi 1984). The PEs approach to resource mobilization and allocation for national socio-economic development is in consonance with the Keynesian approach to economic development particularly since the post 1930 global economic depression (Bos 1986).

On the basis of this developmental approach, the view was held that as African countries progressed towards maturity their PEs would play dominant role in their socio-economic development. The activities of the government (performed by PEs) therefore, spilled to agriculture, mining, manufacturing, banking, insurance, commerce and energy sector. By the mid 1980's the total number of PEs in Africa had reached about 3,000 with cote D'Ivoire, Ghana and Nigeria, housing about 5.24 percent, 6.32 percent and 20.96 percent of that numbe3r, respectively (Swanson and WoldeSemait: 1989).In Nigeria in particular as at 1983,the number of theseenterprises was in no less than 110 enterprises spanning transport,aviation, shipping,oil,vehicle assembly and manufacturing(Anyebe,2002).

Inspite of the large number of PEs in Nigeria, there was usually one central issue of criticism against them. This criticism related to the large share of public finances that the enterprise had steadily absorbed without commensurate benefits. The Value of the federal government's investment in these enterprises was then estimated at about \#17.8 billion(Anyebe,2002) It is generally believed that government ought not be directly involved in what is purely economic activities.

It is againts this backgroud that the Nigerian government embarked on the privitization of Publlic enterprises. The idea of privatization is therefore the outcome of efforts by the liberals to emphasise the virtues' of private initiative and the superiority of its management principles (Adamolekun and Layeye, 1981;1 in Ojobo,2005). Proponents of privatization argue that state control over public enterprises has devasting effects because it involves excessive public intervention inspite of the inherent inefficiency of government. Thus, encouragement of private entrepreneurship, the market and 
perfect competition is recommended as the solution to economic crisis in Nigeria.(Ojobo,2005)

Inspite of its inherents benefits,Privitization has its own negatives effects.One of the main criticisms against the privatization policy has been its negative impact on labour especially the pauperization of the working class through mass retrenchment, increase in the cost of living, erosion of industrial democracy; loss of benefit, often accompanied by lack of social safety nets and functioning labour market (Chotten Panda, 2000; 229).

Therefore, the main objective of this article is to examine the impact of privatization policy on the power sector in Nigeria using the political economy approach. Most studies on privatization in Nigeria have concentrated on other sectors but neglected the consequences (negative and positive) of privatization policy on the power sector.

\subsection{Definitions and Meaning of Privatization.}

The word "privitization" can be define in many ways.It can mean returning public-owned assets to the private sector,usually 'where control of an activity is passed from the public sector to the private sector by means of an issues of shares'(Ohashi and Roth,1980 in Anyebe,2001).This definition is narrow.A more comprehensive definition is to see privitization as a reduction in production,provision,subsidies or regulation,or indeed any combination of the four instruments(Anyebe,2001).The united nations Development Programme (UNDP) Guidelines on Privatization (1991) defines it as the marketisation of the public sector actitvity, that is the subjection of micro-economic decision-making to market forces, since this is a feature of profit-oriented private sector activity. Section 14, Decree No 25 of 1988 defines Privatization as the transfer of government owned shareholding in designated enterprises to private share holders, comprising individuals and cooperate bodies. Ezeani $(2004 ; 24)$ on his own part defines it as a deliberate government policy of stimulating economic growth and efficiency by reducing state interference and broadening the scope of private sector activity through one or all of the following strategies, transfer of state owned assets to private ownership through the sale of shares, private control or management of state owned assets, encouraging private sector involvement in former public activity, and shifting decision making to agents operating in accordance with market indicators. Kayode (1986) sees privatization as a process by the public sector towards the pursuit of efficiency and effectiveness in attainment of objectives with dominance of finance considerations through the adaptation of management styles that reward good and penalize poor performance. Ojobo(2005) on his own part define privatization as the selling of a part or the entire equity of a publicly owned organization to private individuals or organizations such that the control of the public institution is transferred from government or any of its agencies to private hands.

All the definitions above point to the fact that privitization is all about government withdrawal from economic activities,in order to confine itself to its tradition functions of maintenance of law and order,thus creating enabling enviroment for businesses to flourish.

\subsection{Argument in favour of Privatization}

Ojobo (2004 in Ojobo 2005 ) summarized the arguments in favour of privatization as follows:

a. Privatization and concentration of wealth in a few hands do not have to go together, on the Contrary, an even spread of ownership can be achieved with sound planning of privatization;

b. Governments all over the world are not suited to run certain enterprises efficiently. As stated in the business concord editorial of June 7,1985, "The history of public utilities in Nigeria has been such that continued maintenance of these corporations will only amount to general economic myopia",

c. African nations under the economic slump can no more bear the inefficiencies of public enterprises.

d. privatization will improve the efficiencies of the enterprises.

e. privatization is taking place in many countries of the world, including the United State, Britain and Germany.

f. Government can still control enterprises without necessarily owing them. For example the Central Bank of Nigeria controls the commercial banks through prescribing reserve ratio, stipulated credit guidelines.

g. Revenue can be raised for government through better corporate taxation instead of corporate ownership and through the proceeds from the sale of public enterprises.

h. The problems facing most public enterprises can be traced to the fact that they are government owned and this is why they are used for political and other patronages; the managements are not given a free hand to manage and the organizations do not care to collect their debts. Privatization will remove political interference and administrative red tape from public enterprises.

i. privatization will abolish unproductive use of scare national resources, eliminate fraud and embezzlement and infuse financial discipline into these organization . 
j. tight controls by government which might result if these is no privatization is not necessarily in the best interest of the country. For instance, if the government was in complete control of commercial banks in Nigeria, the bank should have embarked on unnecessary retrenchment of workers. Besides watertight control of economy may degenerate into totalitarianism.

k. if public enterprises are privatized, they will generate greater wealth and provide more employment because their efficiency and productivity level will raised.(Ojobo,2005).

In his own contribution,Obadan(2000)summarises the objectives of privitization to includes;

1. General circulating new investment,including foreign investment.

2. Reducing the administative burden of government.

3. Providing opportunity to introduce competition.

4. Improving economic efficiencies against the background of public enterprises.

5. Reducing government interference in the economy and promoting market force in the economic equity.

Inspite of the aforementioned argument in favour of privatization,Ojobo(2005)is of the view that these elaborate arguments in favour of so called market economy are plausible, theoretical and empirical evidence abound to suggest that unregulated free enterprise may after all not work in the best interest of the society. The Great Depression of the 1930s and the recent economic meltdown of 2009 is good case in point. It is indeed argued and experience has shown that that the market determined efficiency pattern of economic activity is not necessarily (and in fact, it hardly ever is) the pattern regarded by society as equitable. Karl (1963 in Ojobo,2005) in his classic work," The Great transformation presents an eloquent and ominous indication of the market system. According to him,

\begin{abstract}
.... The idea of a self -regulating market implied a stark utopia. Such an institution could Not exist for any length of time without annihilating the human and natural substance of a man, today even the most ardent advocates of free enterprise are quick to acknowledge the fundamental weakness of the self-regulating market system and concede to the fact that, to the extent that the system (free enterprise) succeeds, it generate an efficient economy, but that pursuit of efficiency necessarily creates inequalities.
\end{abstract}

Market failure, public goods and externalities and the growth and development factors are a number of grounds used by government to justified to intervention in the economy.Market failure manifest whwn the price system fail to operate in a competitive enviroment as assumed by the advocates of free enterprises.It is a well known fact that perfect competition hardly ever exist in real life.A number of factors ranging from the existence of monopolies,imperfect information of the market combine to limit perfect competition. The manifestations of market failure are even more pronounce in a developing economy where both structural and institutional factors combine to seriously limit the capacity of the prices system to efficiently and equitable allocate resources in the economy(Ojobo,2005).

Again,in performing the allocation function, the price system may not be capable of ensuring that certain line of goods and services are produced in the required amounts and qualities or even produced at all. These goods are mainly in the class of what is loosely called 'public goods'. Public goods, which include defence, education, preventives health, social welfare etc. Are collectively or jointly consumed by all members of the society. Since it may be very difficult, expensive to try to exclude people from consuming such public goods, the profit- motivated private will not be willing to produced them. Again, even when produced, the unit price obtaining them may be out of the reach of majority of the people in the society.

Another related manifestation of failure in the market in the allocation of resources arises when the production or consumption of certain goods or services result in external effects (or involve externalities) that tends to impose hardship on, or deliver benefits to persons who do not have an effective voice in determining the quantity of such goods or services that will be produced. The presence of these external effects means that the supply and demand information used to determine price and outputs in the market system will be distorted- market will not accurately reflect benefits received or costs incurred in the provision of these goods. An efficient allocation of resources will therefore result. Thus the existence of public goods and externalities provide an economic retain for the range of activities undertaken by government.

The market failure argument can also be related to the performance of the distribution function. In this area, markets may fall in the sense that they may not yield the type of distribution desired by society. possibly, the outstanding market characteristic that result in significant income inequality is that market tends to reward participants according to their 'productivity ' and in relation to the demand or market situation for that particular type of labour.

As was well highlighted by Haveman(1976;43 in Ojobo,2005), The market provide very large income for those whose labour command a high price and those who posses particularly valuable land and capital. The market system deals harshly with those of modest skill and those who are without any accumulated or inherited possessions. 
In a society where the bulk of prevailing inequality is brought about and sustained by inequality of access to opportunity, a market determine income structure might tend to grossly misrepresent (understate) the reality. Hence, government will be fully justify to intervene with a view to adjusting the distorted profile income. Although it may argued that factor incomes emerging from the market system adequately reflect societal preference, these (preferences) definitely do not take in to consideration the question of social justice or equity and that is the genes of government intervention in the areas of incomes distribution.

(iii) The third and last reason for government intervention has to do with government's desire to harness available resources in a comprehensive and coordinated manner to hasten the pace of development. Government intervention is therefore very crucial in the development economy where not only are the commodity and factor markets full of imperfections, the financial system (money and capital markets) is usually in the early stages of development. Again the failure of the market to price factors of Production correctly is further assumed to lead to gross disparities between social and private value of alternative investment projects. In the absence of government interference, therefore, the marl said to lead to a mis- allocation of present and future stock of resources.

Proponents of government intervention in developing countries argue that the uncontrolled market economy not only subject these nations to economic stagnation and fluctuating prices, but makes the economy highly susceptibly to eternal domination. Thus, government intervention is general considered, an essential and integral part of development programmes, for market forces, by themes cannot overcome the deep- seated structural rigidities in the economies of the developing count(Helfgoth \&Schiero - camp 1970; 11). In turn, these realities contribute and sustain to the idea.

The state shall taken an active, indeed decisive role in the economy, by its own acts of investment and enterprise, and by its various controls, inducements and restriction - over the price sector the state shall initiate, spur and steer economic development.(Ojobo,2005)

\section{Forms of Privatization in Nigeria}

According to (Ojobo,2005),Privatization takes various forms ranging from divestment to delegation, displacement and decentralization.Divestment implies transfer of public organizations to private ownership of the enterprise. Delegation means that the control of government assets or activities is transferred to private management and government involvement is limited mostly to assessment of results. Examples are leases, concession, management contract etc.

Displacement means that the state passively allows the private sector to expand by promoting active participation of the private sector in former public activities.

In the case of decentralization, decision - making is shifted to other agents that have been operating in accordance with market indicators. It also includes the introduction of private sector ownership and incentives. However the state maintains ownership and ultimate control of the enterprises. An example is the performance contract.(Ojobo,2005).

Table1: Form of privatization

\begin{tabular}{|c|c|c|}
\hline By Divestment & $\begin{array}{l}\text { - Scale } \\
\text { - Free Transfer }\end{array}$ & $\begin{array}{l}\text { - To private buyer } \\
\text { - To the public } \\
\text { - To users/ customers } \\
\text { - To employees }\end{array}$ \\
\hline & & $\begin{array}{l}\text { - To users / customers } \\
\text { - To prior owners (restitute) }\end{array}$ \\
\hline By Delegation & $\begin{array}{l}\text { - Contract } \\
\text { - Fran chaise } \\
\text { - Grant } \\
\text { - Voucher } \\
\text { - Mandate }\end{array}$ & $\begin{array}{l}\text { - Public Domain } \\
\text { (Concession) } \\
\text { - Public assets lease }\end{array}$ \\
\hline By Displacement & $\begin{array}{l}\text { - Default } \\
\text { - Withdrawl } \\
\text { - Deregulation }\end{array}$ & \\
\hline By Decentralizations & $\begin{array}{l}\text { - Transfer of decision - making to agents } \\
\text { - Performance contracts framework document etc. }\end{array}$ & - \\
\hline
\end{tabular}

Source: Savas(1999:822 in Ojobo,2005). 


\section{Theoretical Framework of Analysis}

The theoretical frame work adopted in this paper is Karl Marx's historical or dialectical materialism. According to Marx (1968) historical events are the result of a continuous economic struggle between different classes of groups in a society and the struggle is a conflict between "the mode of production and "the relations of production". The mode of production conditions the social, political and intellect life processes in general. The mode of production refers... to the way in which the means of product were owned and the social relations between men which resulted from their connections with the process of production. It also emphasizes "the importance of domination, exploitation, struggles and control between classes in any mode of production "(Aina 1986:4) Government and the State are instruments used to protect and promote the interests of those in control under capitalism - bourgeoi (Dyke, 1969:168). The theory also emphasizes that the hierarchical structural of the society emanate from the established ways of organizing production and distribution in material and spiritual life, which ensure the unequal exploitation of nature and the results of human work by social classes and group(Ojobo,2005).

Appling this theory to the analysis of privatization, especially in relation to the power sector in Nigeria, it can observed that it (privatization) is a product of the shifting emphasis of international capitalism from the state ownership of the means of production to that of private ownership.

However, the privatization option represents a strategy by indigenous capitalist class in Nigeria (who are also the ruling and governing class) in collaboration with their foreign collaborators to increase their ownership and control of the means of production.Ojobo(2005)was of the view that owning to the Drive for efficiency and profit pursuit by the dominant capitalist class, the privatization policy has led to massive retrenchment of labor, hike in the prices of goods and services beyond the reach of most working class, and the erosion of industries democracy. This is because it is in the interest of capital to downsize the work force, increase prices of goods and services in order to increase the profit, which it enjoys alone.This is what is likely going to befall the power sector in Nigeria.

\section{An Overview of Privatization of Power Sector in Nigeria}

\subsection{Historical overview}

Electric power came to Nigeria in 1898 with the establishment of the first generating plant by the British colonial government (Okoro\&Chikuni, 2007 in Okolobah\&lsmail, 2013). The management of the generating plant was named the Public Works Department (PWD).Thereafter, the then Federal Government of Nigeria passed an ordinance in 1950, establishing the Electricity Corporation of Nigeria (ECN) saddled with the responsibility of generating, transmitting, distributing and sale of electricity in Nigeria. Other bodies like the Native Authorities and the Nigeria Electricity Supply Company (NESCO) had licenses to produce electricity in some locations in Nigeria (Okobolo and Ismail, 2013).

In 1962, the Federal Government by an act of Parliament established the Niger Dam Authority (NDA). The authority was responsible for the construction and maintenance of dams and other works in the River Niger and elsewhere, generate electricity by water power, improve navigation and promote fisheries and irrigation. The electricity produced by NDA is being sold to ECN for distribution and sales at utility voltages. In April 1972, by a decree, Electricity Corporation of Nigeria and Niger Dam Authority were merged to form National Electric Power Authority (NEPA). The reasons given for this merger include: vesting of production and distribution in one company and that it will bring about more efficient utilization of the human, financial and other resources available to the electricity supply industry in the country (Babatunde,. \& Shaibu, 2008).

In 1973, NEPA became operational and was responsible for generating, transmitting and distributing of electricity to all parts of the federation. Starting with only four power stations namely ljora, Delta, Afam thermal stations and Kainji hydro power station with a total installed capacity of 532.6MW serving more than two million customers, which has grown to 5,958MW in year 2000 with the establishment of additional power stations namely Jebba, Shiroro hydro power station Egbin, Sapele, Delta thermal power station in the early eighties having a combined installed generating capacity of 2940MW (PHCN, 2010. Nigeria @ 50: Status of Power sector). In 1988 NEPA was partially commercialized supported by an upward review of the tariffs. This was aimed at attracting investors to the sector.

Due to increase in the population of the country and the absence of additional power plants the available facilities became overstretched and this led to the reform of the power sector. 


\subsection{Power sector reform in Nigeria}

With the return of civil rule in 1999, the federal government embarked on power sector reform. This culminated in the Electric Power Sector Reform (EPSR) Act 2005. This is contained in a Federal Government of Nigeria Gazette and it stipulates the reforms in the electricity power sector and how they are to be implemented. The Power Sector Reform was embarked upon on March, 2005 due to the inadequate supply of electricity, high demands and issues with bills. The main goal of the reform is to accomplish full deregulation of the Electricity Supply Industry (ESI) in two years after its implementation. The objectives include making electricity generation and supply available to consumers, making the sector investor-friendly and dismantling NEPA's monopoly. This was achieved through the passage of the Electric Power Sector Reform (EPSR) Act which came into being on the $11^{\text {th }}$ of March, 2005. The reasons given for the reform include: introduction of competition in the industry as a means of improving industry efficiency that will result in providing lower energy prices to end users, lack of price transparency in utility operations hence consumers and regulators demand price transparency and declaration of cross subsidies among different users, like many other public owned institutions, corruption, inefficiency and managerial incompetence prevailed and the electricity industry showed inconsistent policy direction and lack of strategy framework for its sustainable development, policy decisions by past government in the ESI were based on political or administrative interest instead of efficient resource allocation and cost recovery necessary for economic development and the strategic energy policy for the country was never implemented (Okobolo and Ismail, 2013). The Act repealed the earlier law establishing NEPA, consequently, the Power Holding Company of Nigeria, (PHCN) was set up and charged with the responsibility of providing power supply. It also restructured the power sector from a vertically integrated structure into eighteen unbundled autonomous companies comprising one transmission company called TransCo, six generation companies known as GenCos and eleven distribution companies- DisCos respectively. The Act focused on the liberalization and privatization of the sole power provider-PHCN while introducing Independent Power Producers IPPs. The EPSR Act nurtures a wholesome market stating with a single buyer of electricity produced by PHCN and the IPPs for onward sale to the eleven DisCos that would also be offered for sale. Eventually the single model would be discarded for a bilateral contract model with suppliers and buyers free to contract between themselves (www.mbendi.com).

The Act further provides for the establishment of the Nigeria Electricity Regulatory Commission (NERC) which is charged with the following: (Inugonam, 2005).

- Regulate tariffs and quality service

- Oversee the activities of the industry for efficiency.

- Institutional and enforcement of the regulating regime.

- Licensing of Generation, Distribution, Transmission and Trading companies that result from the unbundling of NEPA.

- Legislative authority to include special conditions in licenses.

- Provision relating to public policy interest in relation to fuel supply, environmental laws, energy conservation, management of scarce resources, promotion of efficient energy, promotion of renewable energy and publication of reports and statistics.

- Providing a legal basis with necessary enabling provisions for establishing, changing, enforcing and regulating technical rules, market rules and standards.

In November, 2005 Nigeria Electricity Regulatory Commission was inaugurated and took full responsibility. Other aspects of the reform provided for the management of the Rural Electrification Agency (REA), the National Electric Liability Management Company (NELMCO) which is a special purpose entity created to manage the residential assets and liability of the defunct NEPA after privatization of the unbundled companies. The Act also provided for the establishment of a Power Consumer Assistance Fund (POLAF) to subsidize under privileged electricity consumers (Balogun, 2010).

However, in spite of these efforts, the problem of the power sector continues until November, 2013 when PHCN was formerly handed to the new investors.

\subsection{The impact of privitasation of power sector in Nigeria}

Owing to the fact that the privitization policy is based on capitalist ideology and oreintation and in its drive for profit,it has led to the following;

a. Retrenchment of many PHCN workers. The reasons adduced for this was that PHCN was over staffed.Even 
though government made effort to compensate the layed-off staff,there are concern that the compensation will not be adequate to cover the entire staff.In fact,Ayodeji(2012)argued that the pension bill of PHCN workers is in the tune of $\mathrm{N} 500$ billion and PHCN is documented to be currently broke having liabilities of over N600 billion .Also ,the N600 billion the government hopes to make from the sale of PHCN cannot settle all the current liabilities of PHCN, which stands at over a trillion Naira .The intentions of the government, he opined, is to dupe PHCN workers by not paying their pensions and crudely handing them over to new employers who are not committed in any way to maintaining their jobs and trade union rights. Massive job losses are inevitable if the government is allowed to have their way.

b. Increase in tariff without commensurate electricity supply. The ordinary consuming masses are at the receiving end as their electricity bills go up multiple folds. Today, scores are incurring huge electricity bills as the new Distribution Companies (DISCOS) tariffs have continued to go up and leaving huge dent in the pockets of toiling masses.

Increment in tariffs and outright deregulation are part of the consequences of the privatization of PHCN. The argument of the government according to Ayodeji(2012) is that price increment and total deregulation of electricity tariff would attract the "foreign investors". However, the privatization program has already entered into major crises as anticipated. For one, we are not seeing the massive inflow of the so-called foreign investors who are supposed to come in with huge foreign exchange to save the electricity sector in Nigeria. Also, electricity supply is worsening by the day.

c. Another concern is that the companies are owned by the few political elites and their fronts. What we are witnessing are companies representing the crude and selfish interests of Nigerian elite class (past presidents, governors, ministers, top government contractors, etc). The same elements that was responsible for the crisis in the first instance. Most of these companies have no experience in the power sector and little or no capacity at all to manage the Nigerian power sector. (Ayodeji, 2012).

d. Concern about transparency. Billions have been spent on government propaganda to polish the fraudulent privatization, however, the objective realities point to the fact that the whole process is corrupt and would land the country in a much bigger crisis. The Minister of Power, Barth Nnaji, was sacked due to his corrupt interests in the process. This is a major indictment.

e. Privitazation of PHCN is also considered a Monumental Rip-off. After announcing the 'winners' of the electricity generating plants and the distribution units, the government declared that it would be making about N600 billion from the sales. According to Ayodeji(2012)N600 billion, which is about $\$ 3.8$ billion, is insignificant when compared to the actual value of PHCN; this is even if these bidders actually pay up, which is never the case in Nigeria. For one, over $\$ 30$ billion have been spent on PHCN within the past ten years alone. Obasanjo regime alone spent over $\$ 16$ billion on power plants the scandal is yet to be cleared up. Yar'dua - Goodluck regime have also spent billions of dollars. Since the inception of Goodluck regime over $\$ 8$ billion have gone into PHCN. In addition, the actual amount spent on building the power infrastructure over the past 52 years is in the tune of over a hundred billion dollars. Only the low level and corrupt mind can jubilate in the face of this obvious monumental rip off. The privatizations of the past have led to the death of most of the privatized public corporation. This reality has been well document - only ten percent of the over 400 privatized government corporations survived. (Ayodeji, 2012).

The current PHCN privatization process is following the exact path that led to the death of those public corporations and utilities. The public corporations were undervalued and sold at give away price. In most cases, those that 'buy' these companies were directly responsible for their problems in the first instance. Privatization is no doubt the process of further plundering the collective wealth created by the working class.

Once these elements take over the companies, the first thing they do is to massively layoff workers and start crudely stripping the various assets of the company. Once the company is strip bare, they dump it and move on. Meanwhile, they paid only part of the amount the offered to buy the company. Hundreds of thousands of workers have been victims of these crimes. PHCN workers instinctively know that privatization will lead to crisis and that they have to fight back in order to defend their lives. More layers in Nigeria are also coming to this realization (Ayodeji,2012).

\section{Conclusion}

This paper has examined the impact of privatization of Power sector in Nigeria using political economy approach. It notes that Nigerian experience so far with privatization shows that it has negative consequences for Nigerians. Some of these negative consequences include retrenchment of the workforce, hike in the prices of goods and services, elitist 
domination, and rip off of PEs among others. It is therefore concluded that in spite of the benefits of higher profit and service delivery, privitazation of $\mathrm{PHCN}$ is not in the best interest of Nigeria nor a viable alternative to the ailing power sector in Nigeria as the government itself is the major contributors to the inefficiency of the power sector .Over the years, appointment is based on patronage rather than merit, as well as inability of PHCN to operate independent of political interference.

\section{Recommendations}

That the power sector has failed to deliver to the expectation of Nigerian is not an understatement. The colossus amount of money expended on the sector is not in tar den with the current poor performance of the sector. It is therefore imperative to reform the sector for better performance. To this end, the following recommendation will suffice thus;

1. There is need for more investors with technical expertise to come into the industry. This will ensure that better service is rendered to consumers at affordable rates.

2. The retrenched staff of PHCN with technical expertise need to be re-engaged back into the service. This will go a long way in alleviating the suffering of the retrenched staff.

3. The Nigeria Electricity Regulatory Commission (NERC) need to regulate the activities of the new companies to ensure that better services are rendered to power consumers.

If these recommendations are adhered to, it will go a long way in improving the situation.

\section{References}

Adamolekum,L and Layeye(1986) "Privatization and the State Control of the Nigerian Economy" Nigerian Journal of Policy and Strategy,NDA Kaduna.

Anyebe,AA (2002) "Readings in Development Administration' 'Shereef Salem Press .Zaria.

Ayodeji A(2012)Oppose the fraud called the Privatization Of PHCN.

Babatunde,M.A \& Shaibu,M.I(2008) "The Demand for Residential Electricity In Nigeria:ABound Testing Approach.

Bos D (1986) Public Enterprise Economics, North Holland.

Chotten-,Panda M(2000)Conceptual Framework for Analyzing Labour Issues in Privatization. Fourth Pan African Privatization Summit, Abuja, Bureau of Public Enterprises.

Dyke V.V (1969) Political Science: A Philosophical Analysis, Stanford University Press.

Ezeani, E.O (1993)Industrial Democracy in Theoretical and Empirical Analysis,Nigerian Journal of Public Administration and Local Government.Vol.6.No.1.

Haveman R,(1976) The Economics of the Public Sector,2nd Edition,John Wiley,New York.

Helfgoth, B \& and Schiero-camp, $F(1970)$ An Introduction to development Planning 'UNIDO Industrial and Productivity Bulletin,16.

Inugonam, T(2009) "Electricity Demand Challenges in Nigeria"PHCN News.Jan-Aug,2009 ed.

Kayode, A. (1986) Public Enterprises and the SAP. Policy Implementation and Implication in Philips and Ndekure(eds)NISER Ibadan.

Marx k(1968) Preface to a contribution to the Critique of Political Economy in Marks and Engels,Selected Works in one Volume,London,Lawrence and Wishart.

Obadan, M.I.(2000)Privatization of Public Enterprises in Nigeria: Issues and conditions for Success in the Second Round, Ibadan: Monograph Series No 1 NCEMA.

Ohashi, T.M and Roth, T (1980) Privatization; Theory and practice (Vancouver: Finaser Institute)

Ojobo, J.A(2005) The impact of Privatization Policy on Labour in Africa:A Political Economy Approach.The Nigerian Journal of Administrative Studies, Vol 3,No 1.

Okolobah,V \& Ismail,Z (2013) "On The Issues,Challenges and Prospects of Electrical Power Sector in Nigeria. International Journal of Economy,Management and Social Sciences.

Okoro,O.I,Govender,P \& Chikuni, E(2007) "Power Sector Reforms in Nigeria:Opportunities and Challenges" Procceedings for 10 International Conference on the domestic use of Energy,Cape Town,South Africa.

Savas E.S( 1971) "Municipal Monopoly"Harpers,

Tanzi N: (1984) Public Enterprises in Mixed Economics.Some Micro-economic Aspects.Washington D.C IMF.

United Nation Development Programme(1991) Guidelines on Privatization, New York,Inter-regional Network on privatization ,Division for Global and Inter regional Programmes. 